\title{
Milk fat responses to dietary supplementation of short- and medium-chain fatty acids in lactating dairy cows
}

\author{
D. Vyas, B. B. Teter, and R. A. Erdman ${ }^{1}$ \\ Animal and Avian Sciences Department, University of Maryland, College Park 20742
}

\begin{abstract}
Short-and medium-chain fatty acids (SMCFA), which are synthesized de novo in the mammary gland, are reduced to a much greater extent than the long-chain fatty acids during diet-induced milk fat depression. Our hypothesis was that SMCFA are limiting for milk fat synthesis even under conditions when milk fat is not depressed. Our objective was to test the potential limitation of SMCFA on milk fat synthesis via dietary supplementation. Sixteen lactating Holstein cows (107 $\pm 18 \mathrm{~d}$ in milk) were fed a corn silage-based total mixed ration. Cows were randomly assigned to groups of 4 per pen and supplemented with 1 of 4 dietary fat supplements $(600 \mathrm{~g} / \mathrm{d})$ supplied in a $4 \times 4$ Latin square design with 21-d experimental periods. Treatments consisted of fat supplements containing mixtures of calcium salts of long-chain fatty acids (Megalac; Church \& Dwight Co. Inc., Princeton, NJ) and an SMCFA mixture (S; $3.3 \% \mathrm{C} 8,7.6 \% \mathrm{C} 10,9.85 \% \mathrm{C} 12,32.12 \% \mathrm{C} 14$, and $47.11 \% \mathrm{C} 16)$ that contained 0, 200, 400, and $600 \mathrm{~g} / \mathrm{d}$ of S substituted for Megalac (S0, S200, S400, and S600, respectively). No treatment effects were observed for dry matter and fat-corrected milk. However, milk yield was decreased with S600. Milk fat increased linearly by $0.17,0.25$, and 0.33 percentage units for the respective $\mathrm{S}$ treatments. However, fat yield peaked at S200 and milk protein concentration and yield was significantly decreased at the higher $\mathrm{S}$ levels because of a linear trend toward decreased milk yield in the S600 treatment. In conclusion, SMCFA supplementation linearly increased milk fat concentration but decreased milk production at the higher levels of supplementation. The dietary inclusion of SMCFA had no effects on total milk fat yield.
\end{abstract} Key words: dairy cow, fatty acid, milk fat

\section{INTRODUCTION}

In 2000, the US Department of Agriculture Federal Milk Marketing System adopted a multiple-component

Received December 19, 2011.

Accepted March 25, 2012.

${ }^{1}$ Corresponding author: erdman@umd.edu pricing system that changed the milk payment system for dairy producers to one based primarily on the amounts of milk components produced rather than milk volume. Among the milk components, milk fat and milk protein are the most valuable as compared with other solids (lactose and minerals; USDA-AMS, 2011). Currently, a large portion of the research effort has been focused on alteration of milk fat components because milk fat responses to dietary manipulations are large as compared with those observed with other milk components (Sutton, 1989). This signifies the importance of understanding the metabolic regulation of milk fat synthesis that would further help in developing practical guidelines for dairy farmers for controlling the quality and quantity of milk fat produced.

Milk fat consists primarily of triglycerides (TG), which include a glycerol backbone and 3 ester-linked FA. The basic mechanism of milk fat synthesis depends on 2 general sources of FA (i.e., de novo FA synthesis in the mammary gland, and transfer of preformed FA from TG in the blood). The short- and medium-chain FA (SMCFA) include FA from $\mathrm{C} 4$ to $\mathrm{C} 14$ and roughly half of C16, which are synthesized de novo in the mammary gland. The long-chain FA (LCFA) originate either from diet or are mobilized from adipose TG as preformed FA (Moore and Steele, 1968). Dietary manipulations can reduce milk fat by $46 \%$ (Piperova et al., 2000). During diet-induced milk fat depression the proportion of de novo-synthesized FA are reduced to a much greater extent than LCFA (Banks et al., 1984; Loor and Herbein, 1998). The alterations in FA composition are attributed to reduced acetyl-CoA carboxylase, a ratelimiting enzyme for de novo FA synthesis (Mellenberger et al., 1973; Baumgard et al., 2002), and FA synthase enzyme activity (Piperova et al., 2000). Under these conditions, de novo FA synthesis might be limiting for milk fat synthesis and the provision of dietary SMCFA in the proportion consistent with synthesized de novo FA might rescue milk fat depression. Abomasal infusion of butterfat, used as a source of SMCFA, increased milk fat yield even under normal conditions of milk fat synthesis (Kadegowda et al., 2008). This led to our hypothesis that SMCFA might be limiting even during normal conditions of milk fat synthesis. The objective 
of our experiment was to test the potential limitation of SMCFA by dietary supplementation on milk fat concentration and yield in lactating dairy cows.

\section{MATERIALS AND METHODS}

\section{Animals, Experimental Design, and Treatments}

All procedures for this experiment were conducted under a protocol approved by the University of Maryland Institutional Animal Care and Use Committee. Sixteen Holstein dairy cows in midlactation (107 \pm 18 DIM) were used in $4 \times 4$ Latin square design balanced for carryover effects. Treatments were as follows: 1) basal diet with $600 \mathrm{~g} / \mathrm{d}$ of Megalac (M; Church \& Dwight Co. Inc., Princeton, NJ) and no SMCFA mix (S; treatment S0), 2) basal diet with $400 \mathrm{~g} / \mathrm{d}$ of $\mathrm{M}$ and $200 \mathrm{~g} / \mathrm{d}$ of S (S200), 3) basal diet with $200 \mathrm{~g} / \mathrm{d}$ of M and $400 \mathrm{~g} / \mathrm{d}$ of S (S400), and 4) basal diet with 600 $\mathrm{g} / \mathrm{d}$ of $\mathrm{S}$ and $0 \mathrm{~g} / \mathrm{d}$ of $\mathrm{M}$ (S600).

The dietary $\mathrm{S}$ consisted of a mixture of $3.3 \% \mathrm{C} 8$; 7.6\% $\mathrm{C} 10,9.9 \% \mathrm{C} 12 ; 32.1 \% \mathrm{C} 14$, and $47.1 \% \mathrm{C} 16$ as FFA (Sigma-Aldrich Corp., St. Louis, MO) corresponding to the proportions of de novo-synthesized FA in milk fat. Short-chain FA, including C4 and C6, could not be added in the FA mixture because of their volatile nature. The fat supplements were thoroughly mixed with concentrates before being incorporated into the basal diet to ensure homogenous mixing. The relative proportions of FA in S are shown in Figure 1.

\section{Experimental Procedure}

Experimental periods were $3 \mathrm{wk}$. The control diet was fed during the first wk of each period to decrease carryover effects. This was followed by 2 wk of treat-

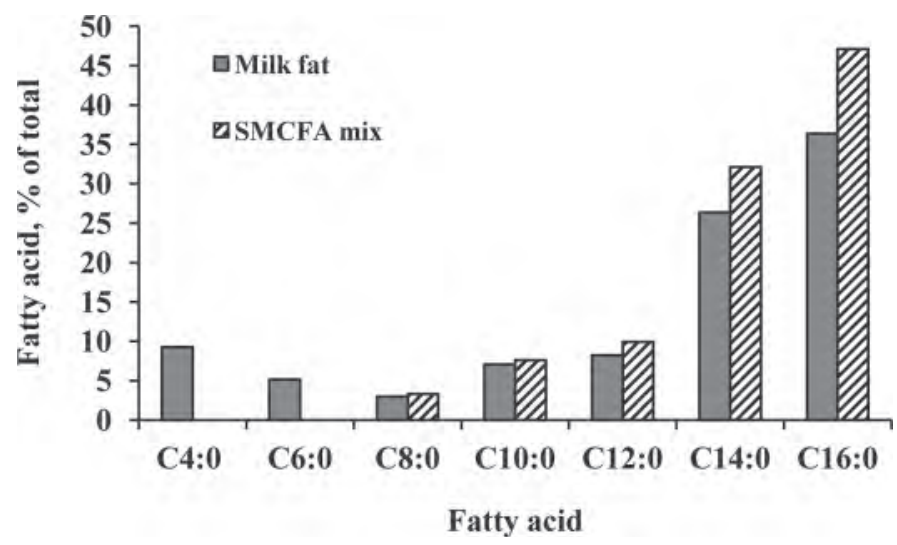

Figure 1. Fatty acid composition of short- and medium-chain FA (SMCFA) mixture relative to de novo-synthesized FA present in milk fat. ment diets. Four cows were randomly allotted to each pen, which included access to sawdust-bedded freestalls. Cows within each pen were group fed. The basal diet contained $56 \%$ forage and $44 \%$ concentrate (DM basis) to meet NRC (2001) nutrient specifications for a $600-\mathrm{kg}$ cow producing $40 \mathrm{~kg}$ of milk containing $3.7 \%$ milk fat and $3.1 \%$ milk protein. The ingredient and chemical composition of the basal diet is given in Table 1. Forage and ingredient DM were measured weekly, and the TMR was adjusted accordingly to maintain a constant forage-to-concentrate ratio on a DM basis. Amounts of feed offered and refused were recorded once daily at $0800 \mathrm{~h}$.

\section{Milk Sampling and Component Analysis}

Cows were milked twice daily at 0700 and $1700 \mathrm{~h}$, and milk production was recorded using an automated milk recording system at each milking. Two sets of milk samples were collected from the last 6 consecutive milkings of wk 3 of each experimental period. One set was collected with preservative for milk fat, protein, and SCC analysis by infrared analysis (Foss MilkoScan; Foss Food Technology Corp., Eden Prairie, MN) and MUN by direct chemical analysis (Bentley ChemSpec; Bentley Instruments Inc., Chaska, MN). A second set of milk samples was composited by cow and frozen at $-20^{\circ} \mathrm{C}$ for subsequent analysis of individual FA.

\section{FA Composition}

Milk fat was extracted using a modified Folch procedure (Christie, 1982). The FA methyl esters (FAME) were prepared by mild transesterification with 1.4 $\mathrm{mol} / \mathrm{L}$ of $\mathrm{H}_{2} \mathrm{SO}_{4}$ in methanol (Christie, 1982). The FAME were analyzed using an Agilent 5890 GC (Agilent Technologies Inc., Santa Clara, CA) equipped with a Supelco 2560 capillary column $(30 \times 0.25$-mm i.d.; Supelco Inc., Bellefonte, PA) and a flame ionization detector. The column was maintained at $150^{\circ} \mathrm{C}$ for $5 \mathrm{~min}$ and was followed by temperature ramping at $1.6^{\circ} \mathrm{C} /$ min to $180^{\circ} \mathrm{C}$, then at $1.4^{\circ} \mathrm{C} / \mathrm{min}$ to $190^{\circ} \mathrm{C}$, and finally holding the temperature at $190^{\circ} \mathrm{C}$ for $10 \mathrm{~min}$. Nitrogen was used as carrier gas with a linear velocity of $25 \mathrm{~cm} / \mathrm{s}$ and split ratio of 1:100. The injection port and detector were maintained at $250^{\circ} \mathrm{C}$. Detector airflow was 222 $\mathrm{mL} / \mathrm{min}$, and hydrogen flow was $36 \mathrm{~mL} / \mathrm{min}$. Helium make-up gas was used at $80 \mathrm{~mL} / \mathrm{min}$. Individual $\mathrm{FA}$ and 18:1 isomers were identified using GLC-463 standard mixture (Nu-Chek Prep Inc., Elysian, MN).

Short-and medium-chain FA were analyzed as butyl esters (FABE), which were mathematically converted to FAME and normalized to the FAME chromatogram (Gander et al., 1962). The original FABE procedure 
Table 1. Ingredient and chemical composition of the basal diet fed to lactating cows

\begin{tabular}{|c|c|}
\hline Composition & Amount \\
\hline \multicolumn{2}{|l|}{ Ingredient, $\%$ of $\mathrm{DM}$} \\
\hline Corn silage & 36.71 \\
\hline Alfalfa hay & 19.59 \\
\hline Corn grain, ground & 19.21 \\
\hline Citrus pulp & 4.66 \\
\hline Soybean meal & 16.22 \\
\hline Corn gluten meal $(60 \%)$ & 0.35 \\
\hline Limestone & 0.73 \\
\hline Calcium phosphate & 0.42 \\
\hline Magnesium oxide & 0.17 \\
\hline Sodium bicarbonate & 0.59 \\
\hline Potassium bicarbonate & 0.11 \\
\hline Dynamate $^{1}$ & 0.11 \\
\hline Salt & 0.39 \\
\hline Trace minerals and vitamins ${ }^{2}$ & 0.18 \\
\hline Megalac $^{3}$ & 0.57 \\
\hline DM, \% & 59.64 \\
\hline \multicolumn{2}{|l|}{ Chemical composition, \% of DM } \\
\hline $\mathrm{CP}$ & 15.71 \\
\hline RUP & $36.62^{4}$ \\
\hline $\mathrm{ADF}$ & 21.51 \\
\hline $\mathrm{NDF}$ & 35.52 \\
\hline $\mathrm{Ca}$ & 0.84 \\
\hline $\mathrm{P}$ & 0.48 \\
\hline $\mathrm{Mg}$ & 0.29 \\
\hline $\mathrm{K}$ & 1.85 \\
\hline $\mathrm{Na}$ & 0.36 \\
\hline $\mathrm{NE}_{\mathrm{L}}, \mathrm{Mcal} / \mathrm{kg}$ & $1.48^{4}$ \\
\hline \multicolumn{2}{|l|}{ FA composition, $g / 100 \mathrm{~g}$ of FA } \\
\hline 14:0 & 0.59 \\
\hline $16: 0$ & 21.86 \\
\hline $16: 1$ & 1.60 \\
\hline 18:0 & 3.65 \\
\hline $18: 1$ & 19.52 \\
\hline $18: 2$ & 33.27 \\
\hline $18: 3$ & 11.90 \\
\hline Other & 7.61 \\
\hline
\end{tabular}

\footnotetext{
${ }^{1}$ Mosaic Co., Plymouth, MN.

${ }^{2}$ Trace mineral and vitamin mix were combined, which provided an additional $0.76 \mathrm{mg}$ of $\mathrm{Co} / \mathrm{kg}, 10 \mathrm{mg}$ of $\mathrm{Cu} / \mathrm{kg}, 5.5 \mathrm{mg}$ of Fe $/ \mathrm{kg}, 0.64 \mathrm{mg}$ of $\mathrm{I} / \mathrm{kg}, 37 \mathrm{mg}$ of $\mathrm{Zn} / \mathrm{kg}, 0.33 \mathrm{mg}$ of $\mathrm{Se} / \mathrm{kg}, 3,526 \mathrm{IU}$ of vitamin $\mathrm{A} / \mathrm{kg}$, $1,175 \mathrm{IU}$ of vitamin $\mathrm{D} / \mathrm{kg}$, and $22 \mathrm{IU}$ of vitamin $\mathrm{E} / \mathrm{kg}$ to the diet DM. ${ }^{3}$ Church \& Dwight Co. Inc., Princeton, NJ.

${ }^{4}$ Calculated value based on the estimated TDN from feed analysis at $3 \times$ maintenance intake using NRC (2001) prediction equations.
}

was modified as follows: milk samples were heated in screw-capped test tubes at $80^{\circ} \mathrm{C}$ for $1 \mathrm{~h}$ in the presence of $1.4 \mathrm{~N} \mathrm{H}_{2} \mathrm{SO}_{4}$ in butanol and then extracted with hexane in the presence of saturated $\mathrm{KCl}$ and distilled water. Samples were then centrifuged at $500 \times g$ for 5 min at $23^{\circ} \mathrm{C}$. An aliquot of the upper hexane layer was injected directly into a Hewlett-Packard 5880 gas chromatograph equipped with a split injector, a flame ionization detector, and a $25 \times 0.2$-mm fused silica capillary column coated with HP1 (Hewlett Packard Co., Avondale, PA). Helium was used as the carrier gas at a flow rate of $2 \mathrm{~mL} / \mathrm{min}$ with a split ratio of $45: 1$. The injector and detector temperatures were set at $250^{\circ} \mathrm{C}$, whereas the column temperature started at $130^{\circ} \mathrm{C}$. The ramp was set at $6^{\circ} \mathrm{C} / \mathrm{min}$ to $290^{\circ} \mathrm{C}$, followed by $4^{\circ} \mathrm{C} /$ min to $260^{\circ} \mathrm{C}$, and finally holding at $260^{\circ} \mathrm{C}$ for $20 \mathrm{~min}$. Standard mixtures, including GLC-60 (Nu-Chek Prep Inc.) were converted to FABE to aid in the identification and quantification of components.

\section{Statistical Analysis}

Dry matter intake, milk production, milk components, and milk FA composition data for cows within each pen were summarized by experimental wk and the pen average per cow from wk 3 was used as the experimental unit in the statistical analyses (SAS, version 9.2; SAS Institute Inc., Cary, NC). Transfer efficiency of individual FA were calculated as the increase in FA output in milk divided by the FA intake. The statistical model included treatments as fixed effects, whereas pen and period were random effects. Treatment effects were tested using linear and quadratic orthogonal contrasts. Significance for all effects was declared at $P \leq 0.05$.

\section{RESULTS}

The nutrient composition of the TMR and FA profile of individual dietary ingredients are presented in Tables 1 and 2, respectively. The total amount of dietary fat supplemented with the basal diet was 509, 539, 569, and $599 \mathrm{~g}$ with S0, S200, S400, and S600 treatments, respectively (Table 3 ). The differences reflect substitution of FFA for Ca salts of FA in Megalac The treatments were designed to provide increasing amounts of SMCFA, including $\mathrm{C} 8, \mathrm{C} 10, \mathrm{C} 12$, and $\mathrm{C} 14$, while keeping C16 constant in all groups.

Production responses to different treatments are shown in Table 4. Treatments had no detectable effects on DMI, $\mathrm{NE}_{\mathrm{L}}$ intake, and 3.5\% FCM. However, a linear reduction $(P=0.03)$ in milk yield occurred with increasing $\mathrm{S}$ that was most pronounced in the S600 treatment. Milk production efficiency $(3.5 \% \mathrm{FCM} / \mathrm{DMI})$ was linearly increased $(P<0.01)$ with $\mathrm{S}$ treatments, reflecting a combination of the small but nonsignificant decreases in DMI and increases in 3.5\% FCM that were observed with S200 and S600 relative to S0.

Milk fat content increased linearly in a dose-responsive manner by $0.17,0.25$, and $0.33 \%$ with S200, S400, and S600, respectively $(P<0.01)$. However, no treatment effects were observed for milk fat yield $(P$ $=0.28)$. Milk protein content and yield increased with S200 $(3.12 \%, 1,373 \mathrm{~g} / \mathrm{d})$ but were linearly $(P<0.05)$ decreased at higher S levels (S400 and S600).

Concentrations (g/100 g of FAME) and yield $(\mathrm{g} / \mathrm{d})$ of individual FA in milk are shown in Tables 5 and 6 , respectively. The concentration of individual shortchain FA (SCFA; C4-C12) were not altered. However, 
Table 2. Fatty acid composition of feed ingredients

\begin{tabular}{|c|c|c|c|c|c|}
\hline FA & $\begin{array}{c}\text { Alfalfa } \\
\text { hay }\end{array}$ & $\begin{array}{l}\text { Corn } \\
\text { silage }\end{array}$ & Corn & $\begin{array}{c}\text { Soybean } \\
\text { meal }\end{array}$ & $\begin{array}{l}\text { Citrus } \\
\text { pulp }\end{array}$ \\
\hline \multicolumn{6}{|l|}{$\mathrm{g} / 100 \mathrm{~g}$ of $\mathrm{FAME}^{1}$} \\
\hline $12: 0$ & 2.19 & 0.57 & & 0.06 & 0.43 \\
\hline $12: 1$ & 0.95 & 0.51 & & & \\
\hline $13: 0$ & 0.39 & 0.33 & & & \\
\hline $13: 1$ & 0.34 & 0.32 & & & \\
\hline $14: 0$ & 0.71 & 0.83 & 0.07 & 0.17 & 0.51 \\
\hline $14: 1$ & 0.81 & 0.61 & & & \\
\hline $15: 0$ & 0.46 & 0.26 & & 0.08 & 0.13 \\
\hline $15: 1$ & 0.28 & 0.26 & & & 0.17 \\
\hline $16: 0$ & 19.71 & 22.43 & 13.62 & 18.15 & 26.01 \\
\hline $16: 1$ & 1.79 & 3.03 & 0.14 & 0.11 & 0.82 \\
\hline $17: 0$ & 0.31 & 0.47 & 0.08 & 0.17 & 0.32 \\
\hline $17: 1$ & 0.52 & 0.69 & & & 0.18 \\
\hline 18:0 & 3.43 & 3.79 & 1.98 & 4.57 & 4.39 \\
\hline 18:1 (cis-9) & 3.89 & 21.64 & 26.63 & 10.58 & 20.39 \\
\hline $18: 1$ (cis-11) & 0.32 & 0.84 & 0.62 & 1.37 & 2.66 \\
\hline $18: 2$ & 18.03 & 24.31 & 53.13 & 54.24 & 33.82 \\
\hline 19:0 & 0.16 & & & & \\
\hline $20: 0$ & 1.20 & 1.44 & 0.45 & 0.20 & 0.49 \\
\hline $18: 3$ & 34.19 & 8.0 & 1.61 & 9.05 & 7.22 \\
\hline $20: 1$ & 0.12 & & 0.39 & & \\
\hline \multicolumn{6}{|l|}{$20: 2$} \\
\hline $20: 3$ & & 0.30 & & & \\
\hline $22: 0$ & 2.10 & 1.92 & 0.19 & 0.44 & 0.45 \\
\hline $22: 1$ & 0.50 & 0.57 & & 0.15 & \\
\hline $24: 0$ & 1.24 & 2.26 & 0.24 & 0.29 & 0.69 \\
\hline $24: 1$ & 2.17 & 0.36 & & & \\
\hline Ether extract, $\%$ of DM & 3.64 & 2.56 & 4.58 & 3.85 & 5.80 \\
\hline
\end{tabular}

${ }^{1}$ Fatty acid methyl ester.

the proportions of medium-chain FA (MCFA) were increased with $\mathrm{S}$ treatment. The myristic acid (C14) content in the milk fat was increased $(P<0.01)$ by 8,19 , and $26 \%$ and yield was increased by 13,24 , and $32 \%$ with S200, S400, and S600, respectively. The myristoleic acid (C14:1) concentration also increased $(P$
$<0.01)$ linearly with $\mathrm{S}$ treatment. The palmitic acid (C16) concentration was increased $(P<0.01)$ by 5 and $7 \%$ with S400 and S600, respectively. However, the C16 yield was not affected. The higher levels of SMCFA supplementation (S200 and S400) decreased $(P<0.01)$ total $\mathrm{C} 18$ content by 13 and $24 \%$, respectively. Further,

Table 3. Amount of individual FA supplemented

\begin{tabular}{|c|c|c|c|c|}
\hline \multirow[b]{2}{*}{$\mathrm{FA}, \mathrm{g} / \mathrm{d}$} & \multicolumn{4}{|c|}{ Treatment $^{1}$} \\
\hline & S0 & S200 & S400 & S600 \\
\hline $8: 0$ & 0.5 & 7.5 & 14.4 & 21.3 \\
\hline 10:0 & 0.2 & 15.0 & 29.9 & 44.7 \\
\hline $12: 0$ & 2.9 & 21.5 & 40.1 & 58.8 \\
\hline $12: 1$ & & 0.2 & 0.5 & 0.7 \\
\hline $14: 0$ & 6.6 & 68.5 & 130.3 & 192.2 \\
\hline $16: 0$ & 273.6 & 276.0 & 278.4 & 280.8 \\
\hline $16: 1$ & 0.7 & 0.4 & 0.2 & \\
\hline $17: 0$ & 0.7 & 0.5 & 0.2 & \\
\hline 18:0 & 23.4 & 15.8 & 8.2 & 0.5 \\
\hline 18:1 (cis-9) & 166.3 & 110.9 & 55.4 & \\
\hline $18: 2$ & 30.8 & 20.5 & 10.3 & \\
\hline 20:0 & 1.7 & 1.2 & 0.6 & \\
\hline $18: 3$ & 0.6 & 0.4 & 0.2 & \\
\hline $20: 1$ & 0.6 & 0.4 & 0.2 & \\
\hline Total, g & 508.5 & 538.7 & 568.8 & 599.0 \\
\hline
\end{tabular}

${ }^{1} \mathrm{~S} 0$ = basal diet with $600 \mathrm{~g} / \mathrm{d}$ of Megalac (M; Church \& Dwight Co. Inc., Princeton, NJ) and no short- and medium-chain FA mix (S); S200 = basal diet with $400 \mathrm{~g} / \mathrm{d}$ of M and $200 \mathrm{~g} / \mathrm{d}$ of S; S400 = basal diet with 200 $\mathrm{g} / \mathrm{d}$ of $\mathrm{M}$ and $400 \mathrm{~g} / \mathrm{d}$ of S; S600 = basal diet with $600 \mathrm{~g} / \mathrm{d}$ of $\mathrm{S}$ and $0 \mathrm{~g} / \mathrm{d}$ of M. 
Table 4. Least squares means for feed intake, milk production, and composition

\begin{tabular}{|c|c|c|c|c|c|c|c|c|}
\hline Item & \multicolumn{4}{|c|}{ Treatment $^{1}$} & SEM & \multicolumn{3}{|c|}{$P$-value ${ }^{2}$} \\
\hline DMI, $\mathrm{kg} / \mathrm{d}$ & 26.6 & 26.4 & 26.5 & 25.5 & 0.53 & 0.24 & 0.12 & 0.26 \\
\hline Milk, kg/d & 43.6 & 43.9 & 42.7 & 41.1 & 1.14 & 0.08 & 0.03 & 0.18 \\
\hline $3.5 \% \mathrm{FCM}, \mathrm{kg} / \mathrm{d}$ & 45.0 & 46.7 & 46.0 & 44.8 & 1.83 & 0.36 & 0.67 & 0.12 \\
\hline $3.5 \% \mathrm{FCM} / \mathrm{DMI}$ & 1.70 & 1.76 & 1.73 & 1.75 & 0.041 & $<0.01$ & 0.03 & 0.16 \\
\hline Milk protein, $\%$ & 3.10 & 3.12 & 3.09 & 3.06 & 0.053 & 0.03 & 0.01 & 0.07 \\
\hline Milk protein, g/d & 1,351 & 1,373 & 1,318 & 1,257 & 41.5 & 0.05 & 0.02 & 0.13 \\
\hline MUN, mg/dL & 10.5 & 10.2 & 10.5 & 10.0 & 0.44 & $<0.01$ & $<0.01$ & 0.29 \\
\hline $\mathrm{SCC}, \times 1,000 / \mathrm{mL}$ & 115 & 118 & 148 & 129 & 2.3 & $<0.01$ & 0.01 & 0.10 \\
\hline
\end{tabular}

${ }^{1} \mathrm{~S} 0$ = basal diet with $600 \mathrm{~g} / \mathrm{d}$ of Megalac (M; Church \& Dwight Co. Inc., Princeton, NJ) and no short- and medium-chain FA (SMCFA) mix (S); S200 = basal diet with $400 \mathrm{~g} / \mathrm{d}$ of M and $200 \mathrm{~g} / \mathrm{d}$ of S; S400 = basal diet with $200 \mathrm{~g} / \mathrm{d}$ of M and $400 \mathrm{~g} / \mathrm{d}$ of S; S600 = basal diet with 600 $\mathrm{g} / \mathrm{d}$ of $\mathrm{S}$ and $0 \mathrm{~g} / \mathrm{d}$ of $\mathrm{M}$.

${ }^{2}$ Probability of a significant effect of short- and medium-chain FA (SMCFA) or of a linear or quadratic effect of increasing amounts of dietary SMCFA.

S600 decreased $(P<0.01)$ total $\mathrm{C} 20 \mathrm{FA}$ content by $24 \%$. Total SFA content was increased $(P<0.001)$ by $6 \%$, whereas MUFA content was decreased by 10 and $12 \%(P<0.001)$ with $\mathrm{S} 400$ and $\mathrm{S} 600$, respectively.

The transfer efficiencies for different SMCFA are shown in Figure 2. The transfer efficiencies were 15.2, 15.9, and 1.4 for C8; 19.3, 2.9, and 0 for C10; 28.7, 16.7, and 11.2 for $\mathrm{C} 12: 0$; and 34.6, 31.9, and 28.4 for C14:0 with S200, S400, and S600, respectively. These values were calculated as the amount of FA excreted in the milk fat expressed as the percentage of the amount added to the TMR by subtracting the SMCFA yields from the S0 treatment.

\section{DISCUSSION}

The purpose of this study was to evaluate the potential limitation of SMCFA on milk fat synthesis in lactating dairy cows. Treatments included incremental amounts of SMCFA substituted for M to keep diets isocaloric. However, the actual amounts of fat supplemented varied with each treatment because of differences in the FA content of individual supplements $(85 \%, \mathrm{M} ; 98 \%$, C8; 97\%, C10; 98\%, C14; and 99\%, C16). Nevertheless, the differences in the total FA supplemented were not large enough to significantly change the interpretation of data. In addition, as desired, the amount of SMCFA supplemented increased, whereas C16 intake was constant in all diets.

No significant treatment effects were observed on DMI. Whereas the effects of SCFA on feed intake are not well documented, MCFA can decrease feed consumption when supplemented at high dietary concentrations. For instance, DMI was significantly decreased with C12 supplemented at 4\% of diet DM (Dohme et al.,
2004). Reduced feed intake was also reported by feeding C14 at 5\% of diet DM (Odongo et al., 2007) and with coconut oil (CNO) containing higher concentrations of C12 and C14 (Storry et al., 1974). Medium-chain FA were shown to disrupt rumen metabolism by decreasing the number of protozoa, depressing fiber degradability, and subsequently depressing intake (Dohme et al., 2001). The amounts of MCFA required to disrupt microbial populations is approximately $4 \%$ of DMI when supplemented with a TMR (Hristov et al., 2009). The MCFA (C12 and C14) made up 40\% of the supplement and the total MCFA intake ranged from 80 to $240 \mathrm{~g} / \mathrm{d}$, which was less than $1 \%$ of DMI. Thus, because of low dietary proportions of MCFA in the present study, significant interaction with the rumen microbes can likely be ruled out. Milk yield in high-producing dairy cows is limited by DMI (Allen, 2000). Therefore, the numerical decrease in milk yield and 3.5\% FCM at higher S levels might reflect the nonsignificant decrease in DMI. A similar response was observed in dairy cows with intraruminal infusion of $\mathrm{C} 12$ and CNO (Hristov et al., 2009).

\section{Milk Fat and FA Composition}

Previous studies have reported variable milk fat responses to individual SMCFA supplemented either as TG or FFA. Intravenous infusion of TG containing SCFA (C3, C4, C6, C8, C9, and C10) showed no effect, whereas infusion of medium-chain TG increased milk fat yield (Storry et al., 1969). Medium-chain FA either decreased (Hristov et al., 2011) or had no effect (Hristov et al., 2009) on fat yield. Coconut oil, used as a source of C12 and C14, either improved (Storry et al., 1971) or had no effect (Hristov et al., 2009) on milk fat yield. 
Table 5. Least squares means for milk FA composition (\%)

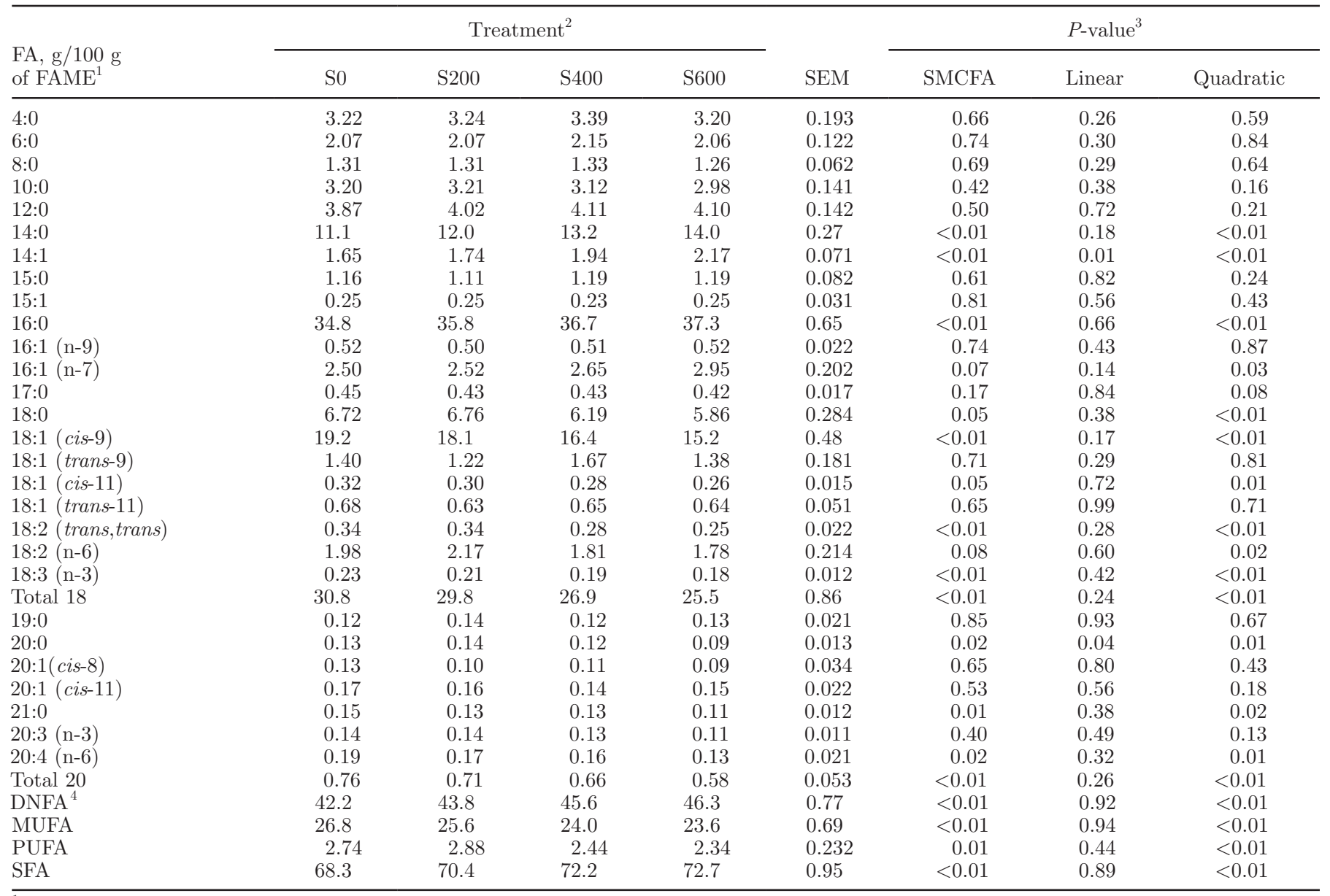

${ }^{1}$ Fatty acid methyl ester.

${ }^{2} \mathrm{~S} 0$ = basal diet with $600 \mathrm{~g} / \mathrm{d}$ of Megalac (M; Church \& Dwight Co. Inc., Princeton, NJ) and no short- and medium-chain FA mix (S); S200 = basal diet with $400 \mathrm{~g} / \mathrm{d}$ of M and $200 \mathrm{~g} / \mathrm{d}$ of S; S400 = basal diet with $200 \mathrm{~g} / \mathrm{d}$ of M and $400 \mathrm{~g} / \mathrm{d}$ of S; S600 = basal diet with $600 \mathrm{~g} / \mathrm{d}$ of S and $0 \mathrm{~g} / \mathrm{d}$ of $\mathrm{M}$.

${ }^{3}$ Probability of a significant effect of short- and medium-chain FA (SMCFA) or of a linear or quadratic effect of increasing amounts of dietary SMCFA.

${ }^{4}$ De novo FA; includes C4:0, C6:0, C8:0, C10:0, C12:0, C14:0, and half of C16 content.

Astrup et al., (1976) found that rumen-protected CNO increased milk fat percentage, whereas unprotected CNO decreased fat percentage. Milk fat output was not significantly altered in the present study. Milk fat yield responses are more apparent when the yields of individual FA are considered. The yield and content of SCFA were maintained, whereas MCFA were increased with $\mathrm{S}$ treatments. The availability of palmitic acid was similar for all treatments, but its secretion numerically increased with $\mathrm{S}$ treatments. This effect could be attributed to chain elongation of dietary SMCFA, as a similar response was observed with intravenous infusion of TG containing SCFA (Storry et al., 1969). The availability of SMCFA along with palmitic acid can affect milk TG synthesis (Hansen and Knudsen, 1987).
Milk fat comprises of 95 to $98 \%$ TG (Jensen, 2002) and mammary TG synthesis involves FA esterification on 3 carbons of the glycerol backbone. Palmitic acid is an important precursor for initiating acylation at the sn-1 position, forming sn-1 lysophosphatidic acid (Hansen and Knudsen, 1987), which subsequently can be used as a substrate for myristyl-, oleoyl-, and stearoyl-CoA acylation (Kinsella and Gross, 1973). Short-chain FA are required for the rate-limiting step of esterification at the sn-3 position, which is catalyzed by diacylglycerol acyl transferase (DGAT; Parodi, 1979) The increased availability of palmitic acid might have increased incorporation of SMCFA during TG synthesis, as reflected in milk fat composition with higher yield of de novo-synthesized FA. However, the responses 
Table 6. Least squares means for yield $(\mathrm{g} / \mathrm{d})$ of milk fatty acids

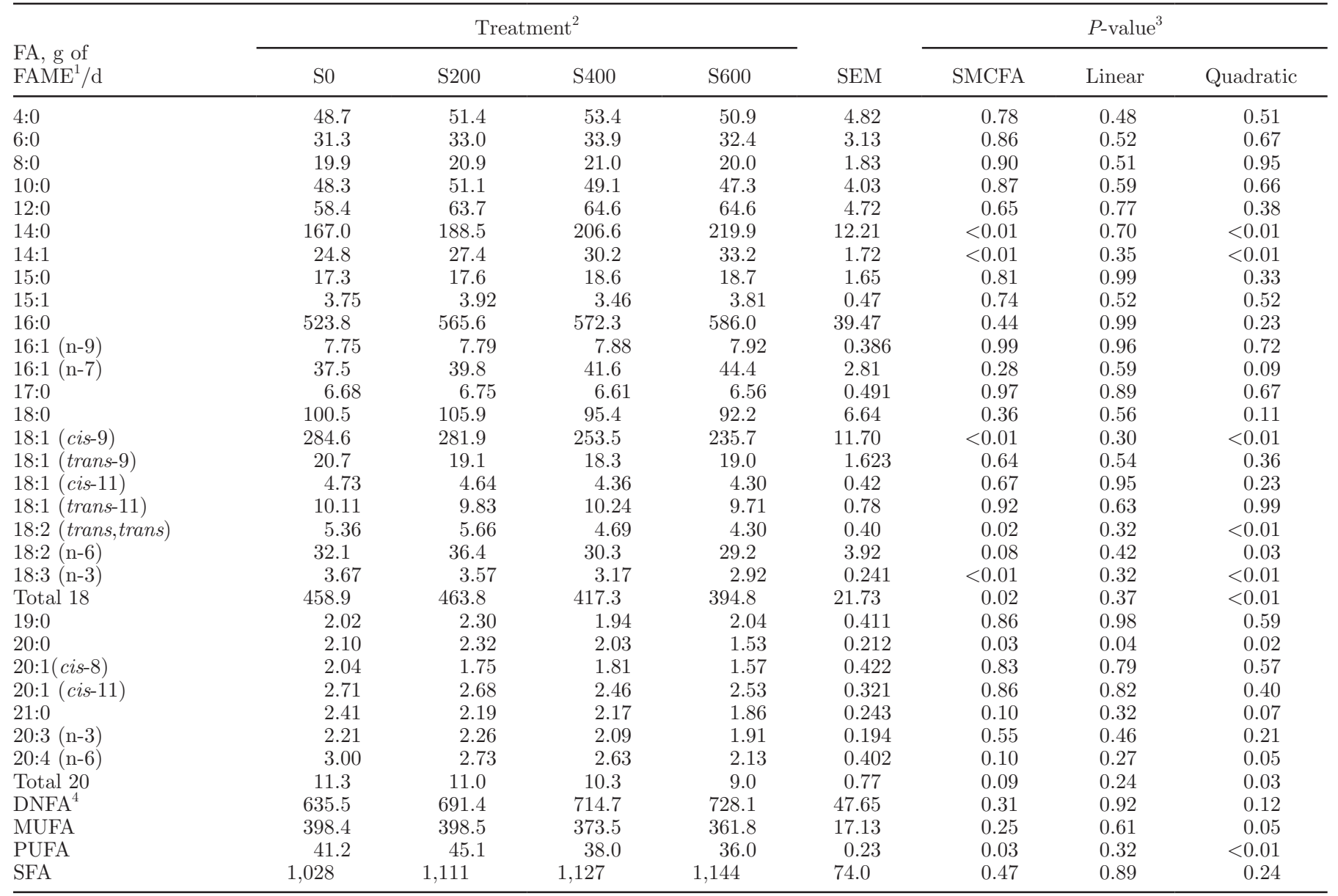

${ }^{1}$ Fatty acid methyl ester.

${ }^{2} \mathrm{~S} 0$ = basal diet with $600 \mathrm{~g} / \mathrm{d}$ of Megalac (M; Church \& Dwight Co. Inc., Princeton, NJ) and no short- and medium-chain FA mix (S); S200 = basal diet with $400 \mathrm{~g} / \mathrm{d}$ of M and $200 \mathrm{~g} / \mathrm{d}$ of S; S400 = basal diet with $200 \mathrm{~g} / \mathrm{d}$ of M and $400 \mathrm{~g} / \mathrm{d}$ of S; S600 = basal diet with $600 \mathrm{~g} / \mathrm{d}$ of S and $0 \mathrm{~g} / \mathrm{d}$ of $\mathrm{M}$.

${ }^{3}$ Probability of a significant effect of short- and medium-chain FA (SMCFA) or of a linear or quadratic effect of increasing amounts of dietary SMCFA.

${ }^{4}$ De novo FA; includes C4:0, C6:0, C8:0, C10:0, C12:0, C14:0, and half of C16 yield.

were not significant because of decreased milk yield at higher levels of SMFCA supplementation. The yield of other LCFA, including C18 and C20, may have been decreased because of decreased dietary supply or substrate competition with SMCFA during TG synthesis (Storry et al., 1969). The increased myristoleic acid yield suggests increased mammary desaturase activity with S treatments (Hristov et al., 2011). The increased proportion and yield of MCFA, including C14:0 and $\mathrm{C} 14: 1$, might increase milk fat fluidity because of the lower melting points of TG containing these FA as compared with LCFA (Odongo et al., 2007).

The SMCFA supplemented in the present study are saturated fats that are suspected to increase coronary heart disease in man by increasing total and low-density lipoprotein (LDL) cholesterol (Williams, 2000; Dohme et al., 2004). The US Dietary Guidelines recommend consuming less than $10 \%$ of the total energy intake from saturated fats (Dietary Guidelines Advisory Committee, 2005). However, the current recommendations focus on overall saturated fat consumption without emphasizing the health effects of individual saturated FA. For example, MCFA, including C8:0 and C10:0, are antiviral agents and the antiviral activity of $\mathrm{C} 10: 1$ was also demonstrated against human immunodeficiency (HIV) virus (Thormar et al., 1994). Antitumor activity of C8:0 was also reported in mice (Burton, 1991). The negative effects of C8:0 and C10:0 on blood cholesterol have not been reported (German and Dillard, 2004). Similarly, the antimicrobial properties of C12:0 were demonstrated against Listeria monocytogenes (Wang et al., 1993), food-borne pathogens, and spoilage bac- 


\section{चC8 घC10 $\mathrm{EC12} \square \mathrm{C} 14$}

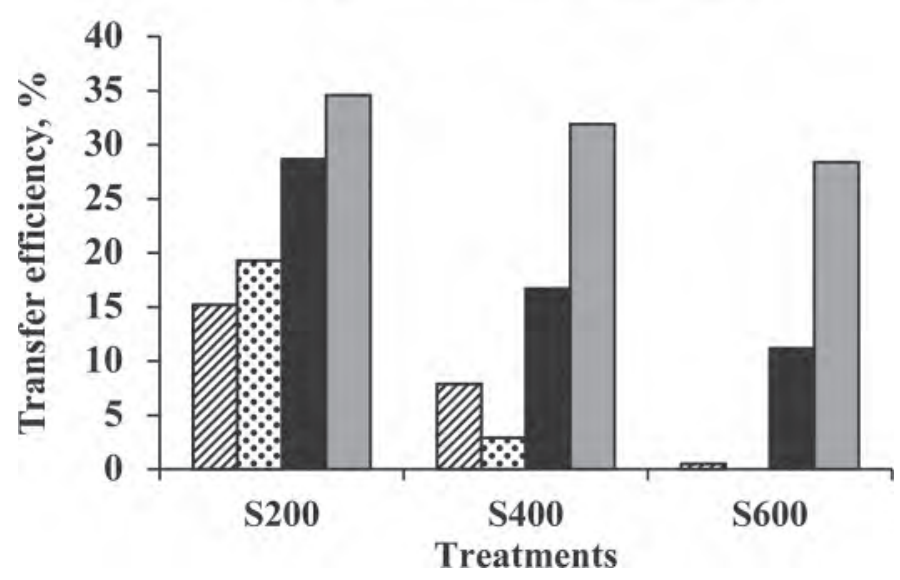

Figure 2. Transfer efficiency of individual short-and medium-chain FA into milk fat of dairy cows fed 200, 400, and $600 \mathrm{~g}$ of SMCFA/d (S200, S400, and S600, respectively).

teria (Ababouch et al., 1992), thereby increasing the hygienic quality and shelf life of milk and milk products (Dohme et al., 2004). Saturated FA (C12:0 and C14:0) are most strongly related to higher blood cholesterol (German and Dillard, 2004). However, Mensink et al. (2003) observed increased high-density lipoprotein (HDL) cholesterol with $\mathrm{C} 12: 0$ and $\mathrm{C} 14: 0$, a change associated with decreased incidences of cardiovascular disorders. The findings from recent epidemiological studies also challenge the association of saturated fats and cardiovascular disorders (Micha and Mozaffarian, 2010; Siri-Tarino et al., 2010). Similar findings were observed with the consumption of saturated fats from milk and dairy foods (German et al., 2009; Elwood et al., 2010). Overall, the concept of consumption of saturated fats as a health concern needs further refinement in terms of intakes of specific SMCFA.

\section{Transfer Efficiency}

Calculated apparent transfer efficiencies of individual FA are affected by their absorption and metabolism. The lower transfer efficiency of SCFA observed at higher levels of supplementation might be because of its preferential utilization by extramammary tissues. Short-chain FA can be absorbed directly from the digestive tract into the portal vein and preferentially oxidized in the liver (Souza and Williamson, 1993). Previous reports in mice and dairy cows have shown extensive hepatic oxidation and decreased incorporation of C8 and C10 in extra hepatic tissues (Storry et al., 1969; Lavau and Hashim, 1978; Souza and Williamson, 1993). Among the MCFA, 11 to $28 \%$ of dietary C12 was transferred in milk fat but the maximal yield of $\mathrm{C} 12$ in milk fat occurred with the lowest level of SMCFA (Table 6). This transfer efficiency is comparable to that of previous reports showing either 18\% (Hristov et al., 2009) or 24 to 26\% (Rindsig and Schultz, 1974; Dohme et al., 2004) of dietary C12 secreted in milk. Dietary C14 was transferred into milk at a rate between 28 and $35 \%$ and total yield increased with increased supplementation. The response is consistent with $39 \%$ transfer efficiency reported previously (Dohme et al., 2004). However, these efficiencies are much greater than those reported by Hristov et al. (2009) and Odongo et al. (2007) of 15 and $12 \%$, respectively. The reasons for such discrepancies are not clear. However, the amounts of C14 supplemented were much higher in previous studies (Odongo et al., 2007; Hristov et al., 2009), which might have decreased transfer efficiency because of extramammary utilization of the supplemented FA.

\section{CONCLUSIONS}

This is the first animal trial studying the effects of increasing amounts of dietary SMCFA on milk fat synthesis. Results indicate that increasing SMCFA linearly increased milk fat percentage. However, no effect was observed for milk fat yield because of depressed DMI and decreased milk yield. Further research is required to determine the mechanism by which these FA affect milk fat synthesis under conditions where DMI is maintained.

\section{ACKNOWLEDGMENTS}

The authors thank Benny Erez, Michael Dwyer, and Brian Spielman at the Central Maryland Research and Education Center (CMREC, College Park) for assistance with feeding and conscientious care of experimental animals during this study.

\section{REFERENCES}

Ababouch, L., A. Chaibi, and F. F. Busta. 1992. Inhibition of bacterial spore growth by fatty acids and their sodium salts. J. Food Prot. 55:980-984.

Allen, M. S. 2000. Effects of diet on short-term regulation of feed intake by lactating dairy cattle. J. Dairy Sci. 83:1598-1624.

Astrup, H. N., L. Vik-Mo, A. Ekern, and F. Bakke. 1976. Feeding protected and unprotected oils to dairy cows. J. Dairy Sci. 59:426430 .

Banks, W., J. L. Clapperton, A. K. Girdler, and W. Steele. 1984. Effect of inclusion of different forms of dietary fatty acid on the yield and composition of cow's milk. J. Dairy Res. 51:387-395.

Baumgard, L. H., E. Matitashvili, B. A. Corl, D. A. Dwyer, and D. E. Bauman. 2002. Trans-10, cis-12 conjugated linoleic acid decreases lipogenic rates and expression of genes involved in milk lipid synthesis in dairy cows. J. Dairy Sci. 85:2155-2163.

Burton, A. F. 1991. Oncolytic effects of fatty acids in mice and rats. Am. J. Clin. Nutr. 53:1082S-1086S. 
Christie, W. W. 1982. Lipid Analysis. 2nd ed. Pergamon Press Ltd., Oxford, UK.

Dietary Guidelines Advisory Committee. 2005. The report of the Dietary Guidelines Advisory Committee on Dietary Guidelines for Americans, 2005. Accessed Feb. 28, 2012. http://www.health.gov/ dietaryguidelines/dga2005/report/.

Dohme, F., A. Machmüller, F. Sutter, and M. Kreuzer. 2004. Digestive and metabolic utilization of lauric, myristic and stearic acid in cows, and associated effects on milk fat quality. Arch. Anim. Nutr. 58:99-116.

Dohme, F., A. Machmüller, A. Wasserfallen, and M. Kreuzer. 2001. Ruminal methanogenesis as influenced by individual fatty acids supplemented to complete ruminant diets. Lett. Appl. Microbiol. $32: 47-51$

Elwood, P. C., J. E. Pickering, D. I. Givens, and J. E. Gallacher. 2010. The consumption of milk and dairy foods and the incidence of vascular disease and diabetes: An overview of the evidence. Lipids 45:925-939.

Gander, G. W., R. G. Jensen, and J. Sampugna. 1962. Analysis of milk fatty acids by gas-liquid chromatography. J. Dairy Sci. 45:323328

German, J. B., and C. J. Dillard. 2004. Saturated fats: What dietary intake? Am. J. Clin. Nutr. 80:550-559.

German, J. B., R. G. Gibson, R. M. Krauss, P. Nestel, B. Lamarche, W. A. van Staveren, J. M. Steijns, L. C. P. G. M. de Groot, A L. Lock, and F. Destaillats. 2009. A reappraisal of the impact of dairy foods and milk fat on cardiovascular disease risk. Eur. J. Nutr. 48:191-203.

Hansen, H. O., and J. Knudsen. 1987. Effect of exogenous long-chain fatty-acids on lipid biosynthesis in dispersed ruminant mammarygland epithelial-cells: Esterification of long-chain exogenous fattyacids. J. Dairy Sci. 70:1344-1349.

Hristov, A. N., C. Lee, T. Cassidy, M. Long, K. Heyler, B. Corl, and R. Forster. 2011. Effects of lauric and myristic acids on ruminal fermentation, production, and milk fatty acid composition in lactating dairy cows. J. Dairy Sci. 94:382-395.

Hristov, A. N., M. V. Pol, M. Agle, S. Zaman, C. Schneider, P. Ndegwa, V. K. Vaddella, K. Johnson, K. J. Shingfield, and S. K. R. Karnati. 2009. Effect of lauric acid and coconut oil on ruminal fermentation, digestion, ammonia losses from manure, and milk fatty acid composition in lactating cows. J. Dairy Sci. 92:5561-5582.

Jensen, R. G. 2002. The composition of bovine milk lipids: January 1995 to December 2000. J. Dairy Sci. 85:295-350.

Kadegowda, A. K. G., L. S. Piperova, P. Delmonte, and R. A. Erdman. 2008. Abomasal infusion of butterfat increases milk fat in lactating dairy cows. J. Dairy Sci. 91:2370-2379.

Kinsella, J. E., and M. Gross. 1973. Palmitic acid and initiation of mammary glyceride synthesis via phosphatidic acid. Biochim. Biophys. Acta 316:109-113.

Lavau, M. M., and S. A. Hashim. 1978. Effect of medium chain triglyceride on lipogenesis and body fat in the rat. J. Nutr. 108:613-620.

Loor, J. J., and J. H. Herbein. 1998. Exogenous conjugated linoleic acid isomers reduce bovine milk fat concentration and yield by inhibiting de novo fatty acid synthesis. J. Nutr. 128:2411-2419.

Mellenberger, R. W., D. E. Bauman, and D. R. Nelson. 1973. Fatty acid and lactose synthesis in cow mammary tissue. Biochem. J. 136:741-748
Mensink, R. P., P. L. Zock, A. D. Kester, and M. B. Katan. 2003. Effects of dietary fatty acids and carbohydrates on the ratio of serum total to HDL cholesterol and on serum lipids and apolipoproteins. Am. J. Clin. Nutr. 77:1146-1155.

Micha, R., and D. Mozaffarian. 2010. Saturated fat and cardiometabolic risk factors, coronary heart disease, stroke and diabetes: A fresh look at the evidence. Lipids 45:893-905.

Moore, J. H., and W. Steele. 1968. Dietary fat and milk fat secretion in cow. Proc. Nutr. Soc. 27:66-70.

NRC. 2001. Nutrient Requirements of Dairy Cattle. 7th rev. ed. Natl. Acad. Sci., Washington, DC.

Odongo, N. E., M. M. Or-Rashid, E. Kebreab, J. France, and B. W. McBride. 2007. Effect of supplementing myristic acid in dairy cow rations on ruminal methanogenesis and fatty acid profile in milk. J. Dairy Sci. 90:1851-1858.

Parodi, P. W. 1979. Stereospecific distribution of fatty-acids in bovine milk-fat triglycerides. J. Dairy Res. 46:75-81.

Piperova, L. S., B. B. Teter, I. Bruckental, J. Sampugna, S. E. Mills, M. P. Yurawecz, J. Fritsche, K. Ku, and R. A. Erdman. 2000 Mammary lipogenic enzyme activity, trans fatty acids and conjugated linoleic acids are altered in lactating dairy cows fed a milk fat-depressing diet. J. Nutr. 130:2568-2574.

Rindsig, R. B., and L. H. Schultz. 1974. Effect of feeding lauric acid to lactating cows on milk composition, rumen fermentation, and blood lipids. J. Dairy Sci. 57:1414-1419.

Siri-Tarino, P. W., Q. Sun, F. B. Hu, and R. M. Krauss. 2010. Metaanalysis of prospective cohort studies evaluating the association of saturated fat with cardiovascular disease. Am. J. Clin. Nutr. 91:535-546.

Souza, P. F. A., and D. H. Williamson. 1993. Effects of feeding medium-chain triacylglycerols on maternal lipid-metabolism and pup growth in lactating rats. Br. J. Nutr. 69:779-787.

Storry, J. E., P. E. Brumby, A. J. Hall, and V. W. Johnson. 1974 Response of lactating cow to different methods of incorporating casein and coconut oil in diet. J. Dairy Sci. 57:61-67.

Storry, J. E., A. J. Hall, and V. W. Johnson. 1971. Effects of increasing amounts of dietary coconut oil on milk-fat secretion in cow. J. Dairy Res. 38:73-77.

Storry, J. E., B. Tuckley, and A. J. Hall. 1969. The effects of intravenous infusions of triglycerides on the secretion of milk fat in the cow. Br. J. Nutr. 23:157-172.

Sutton, J. A. 1989. Altering milk composition by feeding. J. Dairy Sci. 72:2801-2814.

Thormar, H., E. E. Isaacs, K. S. Kim, and H. R. Brown. 1994. Inactivation of visna virus and other enveloped viruses by free fatty acids and monoglycerides. Ann. N. Y. Acad. Sci. 724:465-471.

USDA-AMS. 2011. Milk price announcements, summaries, and product prices. Accessed Sep. 7, 2011. http://www.ams.usda.gov/ AMSv1.0/getfile?dDocName=STELPRDC5093484\&acct=dmkto rd.

Wang, L., B. Yang, K. L. Parkin, and E. A. Johnson. 1993. Inhibition of Listeria monocytogenes by monoacylglycerols synthesized from coconut oil and milk fat by lipase-catalyzed glycerolysis. J. Agric. Food Chem. 41:1000-1005.

Williams, C. M. 2000. Dietary fatty acids and human health. Ann. Zootech. 49:165-180. 